TEKNIK, 41 (1), 2020, 20-26

\title{
Studi Korosi Baja Galvanis Melalui Perlakuan Ekspos Di Lingkungan Perairan Sungai Cidaho - Sukabumi
}

\author{
Ahmad Royani ${ }^{1}$, Gadang Priyotomo ${ }^{1}$, Hadi Gunawan ${ }^{2}$, Joko Triwardono ${ }^{1}$, Lutviasari Nuraini ${ }^{1}$, \\ Siska Prifiharni ${ }^{1}$, Heri Nugraha ${ }^{1}$, Sugiarti $^{1}$, Sundjono ${ }^{1}$ \\ ${ }^{1}$ Pusat Penelitian Metalurgi dan Material - Lembaga Ilmu Pengetahuan Indonesia \\ Gedung 470, Kawasan Puspiptek - Tangerang Selatan, Indonesia 15314 \\ ${ }^{2}$ Pusat Penelitian dan Pengembangan Jalan dan Jembatan, Kementerian Pekerjaan Umum dan Perumahan Rakyat \\ Jl. A.H. Nasution No. 264 Bandung - Jawa Barat, Indonesia 40294
}

\begin{abstract}
Abstrak
Penelitian ini bertujuan untuk mempelajari korosi pada baja galvanis setelah diekspos di Sungai Cidaho Wilayah Sukabumi, Jawa Barat. Kehilangan berat baja galvanis diukur dengan metode pengurangan berat setelah diekspos untuk periode waktu tertentu di permukaan air sungai dan kedalaman air 1 meter. Morfologi permukaan dan komposisi produk korosinya dianalisis menggunakan Scanning Electron Microscopy (SEM) - Energy Dispersive Spectroscopy (EDS) dan X-Raya Diffraction (XRD). Setelah diekspos, seluruh permukaan baja galvanis tertutup oleh produk korosi. Hasil berat yang hilang dari baja galvanis setelah diekspos 76 hari adalah $1,37 \mathrm{mg} / \mathrm{cm}^{2}$ pada permukaan air sungai dan 7,83 $\mathrm{mg} / \mathrm{cm}^{2}$ untuk kedalaman air 1 meter. Peningkatan kerusakan dari baja galvanis ini terjadi karena tidak terbentuk lapisan protektif akibat tergerus arus sungai. Produk korosi yang dominan pada baja galvanis yang diekspos pada kedalaman 1 meter adalah senyawa Zincite $(\mathrm{ZnO})$. Hasil ini mengindikasikan bahwa penggunaan baja galvanis tidak cocok untuk lingkungan di kedalaman air.
\end{abstract}

Kata kunci: baja galvanis; ekspos; korosi; SEM-EDS; senyawa Zincite; sungai Cidaho; XRD

\begin{abstract}
[Title: Study of Corrosion on Galvanized Steel After Exposure in The Water Environment of Cidaho River - Sukabumi] In the study, the behavior of galvanized steel has been studied within the Cidaho River, Sukabumi-West Java. The heavy mortality of galvanized steel is determined by the weight loss method after being exposed for a certain period in river surface and 1 meter water depth. The surface morphology and chemical composition of the corrosion products were analyzed by using Scanning Electron Microscopy (SEM) - Energy Dispersive Spectroscopy (EDS) and X-Ray Diffraction (XRD). After exposure, all galvanized steel surfaces are covered by corrosion products. The result of weight loss of galvanized steel after being exposed to 76 days were $1.37 \mathrm{mg} / \mathrm{cm}^{2}$ in the river surface and $7.83 \mathrm{mg} / \mathrm{cm}^{2}$ in 1 meter depth. Increased damage from galvanized steel in water depth occurs because there was no eroded current protective layer formed. The dominant corrosion product in galvanized steel which has been exposed in 1 meter water depth was Zincite $(\mathrm{ZnO})$. These results indicate that the use of galvanized steel is not recommended in the depth of water.
\end{abstract}

Keywords: galvanized steel; exposed; corrosion; SEM-EDS; Zincite; Cidaho river; XRD

\section{Pendahuluan}

Korosi dan perbaikan akibat korosi adalah masalah besar. Meskipun korosi adalah fenomena alami, dan tidak pernah dapat sepenuhnya dihilangkan, namun sistem perlindungan korosi yang tepat dapat secara

\footnotetext{
${ }^{*}$ Penulis Korespondensi.

E-mail: ahmad.royani@lipi.go.id
}

drastis menurunkan biaya perbaikan akibat korosi. Penggunaan baja galvanis mampu mengurangi biaya dan bebas perawatan. Selama lebih dari 100 tahun, baja galvanis telah digunakan secara luas untuk komponen struktur di berbagai industri, jembatan dan fasilitas umum lainnya. Baja galvanis lebih tahan terhadap korosi daripada besi atau baja. Sama seperti dengan baja, zinc terkorosi ketika kontak dengan lingkungan. Namun, laju 


\section{TEKNIK, 41 (1), 2020, 21}

korosi zinc sekitar 1/10 sampai 1/30 dari laju korosi baja tergantung dari lingkungan atmosfer (Irving $d k k ., 1952$ ). Oleh karena itu, kinerja baja galvanis bervariasi dari lingkungan ke lingkungan (Moniruzzaman $d k k ., 2013$ ). Karena bertahun-tahun baja galvanis telah digunakan untuk perlindungan korosi, banyak data ekspos jangka panjang pada berbagai lingkungan tersedia (Bednar $d k k$; Roseana $d k k ., 2015)$. Banyak faktor yang mempengaruhi karakteristik dan sifat dari produk korosi di lingkungan atmosferik. Faktor-faktor yang mempengaruhi korosi di lingkungan atmosferik antar lain suhu, kelembaban relatif (RH), kadungan sulfur dioksida (SOx), kandungan hidrogen sulfida $\left(\mathrm{H}_{2} \mathrm{~S}\right)$, kandungan klorida (Cl), curah hujan, partikel, bagian logam yang terekspos udara dan lokasi geografis (Sundjono $d k k ., 2017$ ). Sedangkan faktor-faktor yang berpengaruh terhadap laju korosi di lingkungan perairan antara lain adalah suhu, kecepatan fluida, oksigen terlarut (DO), total padatan terlarut (TDS), konduktivitas air, kesadahan air, pH, alkalinitas dan indeks saturasi (Revie and Uhlig 2008).

Baja galvanis banyak digunakan karena galvanis memiliki dua fungsi sifat pelindung. Sebagai lapisan proteksi, galvanis menyediakan lapisan zinc yang tangguh dan terikat secara metalurgi yang sepenuhnya menutupi permukaan baja dan melindungi baja dari serangan korosif lingkungan. Selain itu, terjadinya anoda korban dari zinc yang melindungi baja, sehingga kerusakan atau diskontinuitas minim terjadi (Rita et al.; Shuan dkk., 2013). Lapisan galvanis telah terbukti kinerjanya dalam berbagai kondisi lingkungan. Ketahanan korosi lapisan zinc ditentukan terutama oleh ketebalan lapisan tetapi bervariasi tergantung dari tingkat korosivitas lingkungan (Shuan $d k k ., 2013$ ).

Perkiraan masa pakai (life time) pelapisan penting untuk perencanaan dan penganggaran dalam pemeliharaan yang diperlukan. Pengukuran tingkat aktual konsumsi lapisan galvanis selama beberapa tahun pertama sering memberikan data yang baik untuk memproyeksikan sisa masa pakai hingga pemeliharaan selanjutnya (Bednar $d k k$., 2015). Oleh karena itu, prediksi masa pakai untuk perawatan berdasarkan tingkat korosi awal lapisan zinc sering konservatif.

Pada penelitian ini dilakukan uji performa baja galvanis pada lingkungan air sungai dengan variasi kedalaman selama 27 hari dan 76 hari. Tujuan utama dari penelitian ini untuk menentukan tingkat kerusakan baja galvanis dalam air sungai dan mempelajari korelasi parameter kualitas air terhadap laju korosi baja galvanis tersebut.

\section{Bahan dan Metode}

Penelitian korosi baja galvanis ini dilakukan pada bulan Agustus - November 2017 di perairan sungai Cidaho Kabubaten Sukabumi - Jawa Barat. Lokasi pengujian spesimen secara geografis berada sekitar $1,2 \mathrm{~km}$
(6 ${ }^{\circ} 58^{\prime} 13.5^{\prime \prime S} 106^{\circ} 3128.6^{\prime \prime E ~-6.970427, ~ 106.524611) ~ d a r i ~}$ pinggir pantai laut selatan wilayah Sukabumi seperti pada peta dalam Gambar 1.

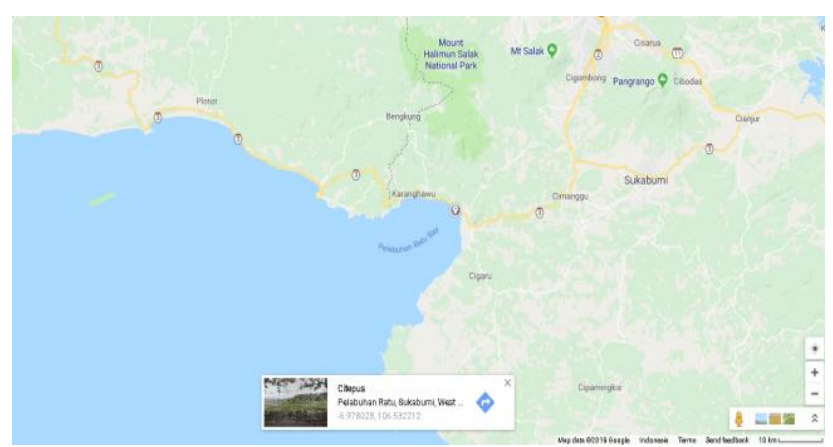

Gambar 1. Peta lokasi pengujian spesimen.

Material yang digunakan dalam penelitian ini berupa baja galvanis yang diperoleh dipasaran. Komposisi kimia baja disajikan dalam Tabel 1 dengan tebal lapisan galvanis sebesar 50,9 $\mu \mathrm{m}$.

Tabel 1. Komposisi kimia spesimen baja galvanis.

\begin{tabular}{cccccccccc} 
Unsur & $\mathbf{F e}$ & $\mathbf{C}$ & $\mathbf{S i}$ & $\mathbf{P}$ & $\mathbf{M n}$ & $\mathbf{N i}$ & $\mathbf{C r}$ & $\mathbf{C u}$ & $\mathbf{T i}$ \\
\hline$\%$ berat & 99 & 0,13 & 0,11 & 0,02 & 0,29 & 0,01 & 0,30 & 0,01 & 0,01 \\
\hline (Sumber: Prifiharni $d k k ., 2108)$ & & & & & &
\end{tabular}

\subsection{Preparasi Material}

Lembaran plat baja galvanis dipotong berbentuk persegi panjang dengan ukuran $150 \mathrm{x} 80 \mathrm{x}$ $2 \mathrm{~mm}$ dan diberi kode pada sisi kiri atas. Sebelum dan sesudah ekspos, sampel dibersihkan sesuai dengan standard ASTM G-1 (ASTM 1999). Setelah dibersihkan, dilakukan pengukuran dimensi dan penimbangan kemudian disimpan ke dalam desikator. Pemasangan spesimen menggunakan rak uji seperti pada Gambar 2.

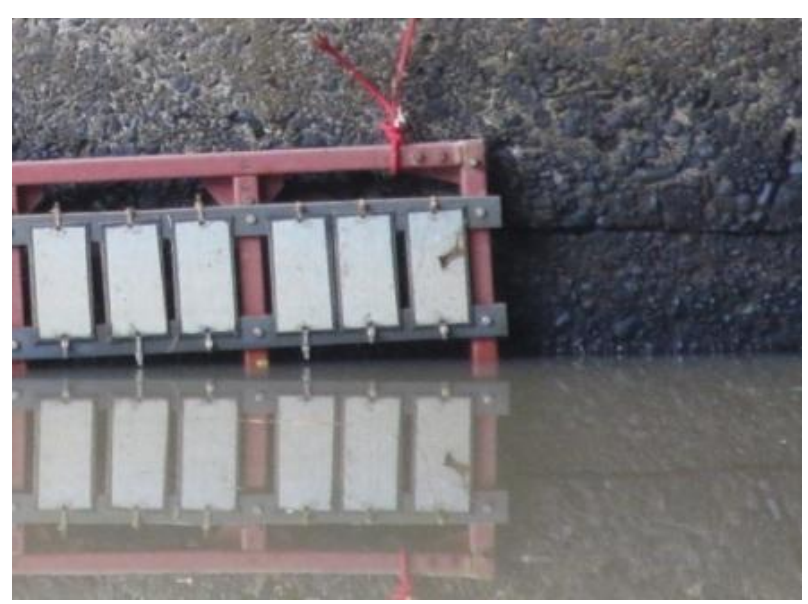

Gambar 2. Perakitan spesimen pada rak uji. 


\section{TEKNIK, 41 (1), 2020, 22}

\subsection{Analisis Kehilangan Berat}

Analisis kehilangan berat dilakukan dengan menimbang sampel spesimen sebelum dan sesudah ekspos. Metode untuk menentukan kerusakan spesimen berdasarkan kehilangan berat mengikuti Persamaan 1 .

$$
\text { Kehilangan Berat }=\frac{\left(W_{o}-W_{1}\right)}{A}
$$

Dimana Wo adalah berat awal $(\mathrm{mg}) ; \mathrm{W}_{1}$ adalah berat akhir (mg) dan A adalah luas area $\left(\mathrm{cm}^{2}\right)$.

\subsection{Analisis Parameter Kualitas Air}

Analisis parameter kualitas air sungai meliputi kandungan oksigen terlarut (DO), konduktivitas, salinitas, suhu dan $\mathrm{pH}$ air serta kandungan padatan terlarut (TDS) diukur dengan alat portabel meter Multi-Hach (HQ40d). Kesadahan dan alkalinitas air diukur dengan metode titrasi. Proses pengukuran parameter kualitas air sungai dilakukan pada awal pemasangan dan pada setiap pengambilan sampel spesimen uji (Royani $d k k$., 2019).

\subsection{Analisis Produk Korosi}

Analisis produk korosi yang terbentuk meliputi morfologi permukaan dan senyawa produk korosi. Morfologi dari lapisan produk korosi yang terbentuk pada permukaan sampel baja galvanis dianalisis dengan menggunakan Scanning Electron Microscope (SEM JEOL JSM-6390A) dan Energy Dispersive Spectrometer $(E D S)$ pada jarak kerja $10 \mathrm{~mm}$ dan tegangan akselerasi 2 $\mathrm{kV}$. Sedangkan senyawa produk korosi yang terbentuk dianalisis dengan menggunakan X-Ray Diffraction (Shimadzu XRD 7000).

\section{Hasil dan Pembahasan \\ 3.1 Indeks Kejenuhan Air}

Indeks kejenuhan air atau dikenal dengan Langlier Saturation Index (LSI) merupakan ukuran stabilitas air sehubungan dengan pembentukan deposit atau korosi. Jika nilai LSI positif, maka air cenderung membentuk deposit, dan ketika nilai LSI negatif, maka cenderung korosif.

Kecenderungan Indeks kejenuhan air (LSI) dihitung dari data hasil pengukuran air dalam Tabel 2 . Dari hasil pengujian nilai kesadahan kalsium dan alkalinitas total masing-masing sebesar 2,7 ppm dan 29 ppm, maka indeks LSI pada $27,1{ }^{\circ} \mathrm{C}$ diperoleh sebagai Persamaan 2 dan 3.

$$
\begin{aligned}
& \mathrm{LSI}=\mathrm{pH}-\mathrm{pHS} \\
& \mathrm{pHS}=(9,3+\mathrm{A}+\mathrm{B})-(\mathrm{C}+\mathrm{D})
\end{aligned}
$$

dimana A adalah $[\log (332)-1] / 10=0,152 ; \mathrm{B}$ adalah $13,12 \times \log \left(27,1^{\circ} \mathrm{C}+273\right)+34,55=2,048$, sedangkan $\mathrm{C}$ adalah $\log (2,7)-0,4=0,031$ dan $\mathrm{D}$ adalah $\log (29)=$
1,462. Sehingga LSI air sungai pada suhu pada $27,1{ }^{\circ} \mathrm{C}$ sebesar:

$$
\begin{aligned}
\mathrm{pHS} & =(9,3+0,152+2,048)-(0,031+1,462) \\
& =10,007 \\
\text { LSI } & =6,92-10,007 \\
& =-3,087 \text { (Negatif) }
\end{aligned}
$$

dimana hasil indeks LSI bernilai negatif, sehingga kecenderungan air sungai membentuk korosi.

Perubahan berat dari baja galvanis terhadap waktu ekspos di lingkungan air sungai ditunjukkan pada Gambar 3. Pada permukaan air sungai, perubahan berat relatif stabil selama waktu ekspos 27 hari dan 76 hari. Sedangkan pada kedalaman 1 meter, perubahan berat meningkat dari 27 hari ke 76 hari. Data hasil perubahan berat pada Gambar 3, menunjukkan bahwa kehilangan berat baja galvanis di kedalaman 1 meter lebih tinggi daripada di permukaan air. Hasil visualisasi spesimen memperkuat bahwa kerusakan baja galvanis di kedalaman 1 meter jauh lebih parah dibandingkan pada kerusakan di permukaan air. Hasil visualisasi spesimen baja galvanis setelah di ekspos selama 76 hari ditunjukkan pada Gambar 4.

Baja galvanis yang diekspos dipermukaan air sungai memiliki berat hilang lebih kecil dibandingkan dengan di kedalaman 1 meter karena terbentuk lapisan pelindung. Lapisan pelindung pada baja galvanis terbentuk menurut mekanisme reaksi sebagai berikut ini:

Pada daerah anoda terjadi pelarutan Zinc (Zn) menjadi ion $\mathrm{Zn}^{++}$, seperti terlihat pada Persamaan 4 .

$$
\mathrm{Zn} \rightarrow \mathrm{Zn}^{++}+2^{\mathrm{e}-}
$$

Sedangkan pada daerah katoda terjadi reaksi seperti terlihat pada Persamaan 5.

$$
\mathrm{H}_{2} \mathrm{O}+1 / 2 \mathrm{O}_{2}+2^{\mathrm{e}^{-}} \rightarrow 2 \mathrm{OH}^{-}
$$

Pada peristiwa korosi tersebut, ion Zinc $\left(\mathrm{Zn}^{++}\right)$ yang terbentuk di daerah anoda bereaksi dengan ion hidroksil $\left(\mathrm{OH}^{-}\right)$dari elektrolit membentuk zinc hydroxide berupa lapisan tipis pada permukaan logam dan dapat mencegah terkorosinya zinc lebih lanjut, seperti terlihat pada Persamaan 6.

$$
\mathrm{Zn}^{++}+2 \mathrm{OH}^{-} \rightarrow \mathrm{Zn}(\mathrm{OH})_{2}
$$

Pada kedalaman 1 meter, kerusakan baja galvanis lebih besar dikarenakan air cenderung besifat korosif sesuai hasil dari perhitungan indek kejenuhan air (LSI). Selain itu dimungkinkan lapisan penghambat pada baja galvanis tidak sempat terbentuk karena tergerus oleh aliran arus sungai. Berbeda jika dalam kondisi statis, maka akan terbentuk deposit atau scale alami dari garam yang tidak larut pada permukaan baja galvanis (Rose $d k k$., 2012). Deposit tersebut, bergabung dengan zinc untuk membentuk lapisan penghalang berupa kalsium karbonat dan zinc karbonat yang memperlambat laju korosi (Merajul $d k k$., 2014). 


\section{TEKNIK, 41 (1), 2020, 23}

\section{Baja Galvanis}

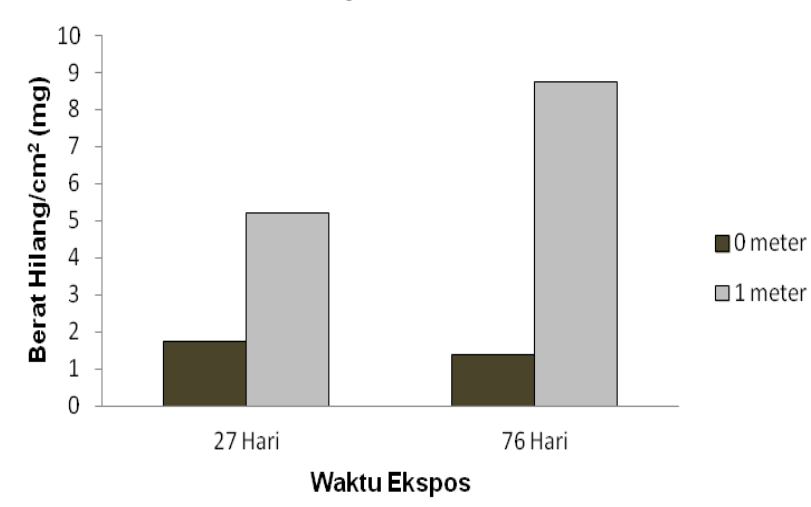

Gambar 3. Laju korosi baja galvanis $v s$ waktu.
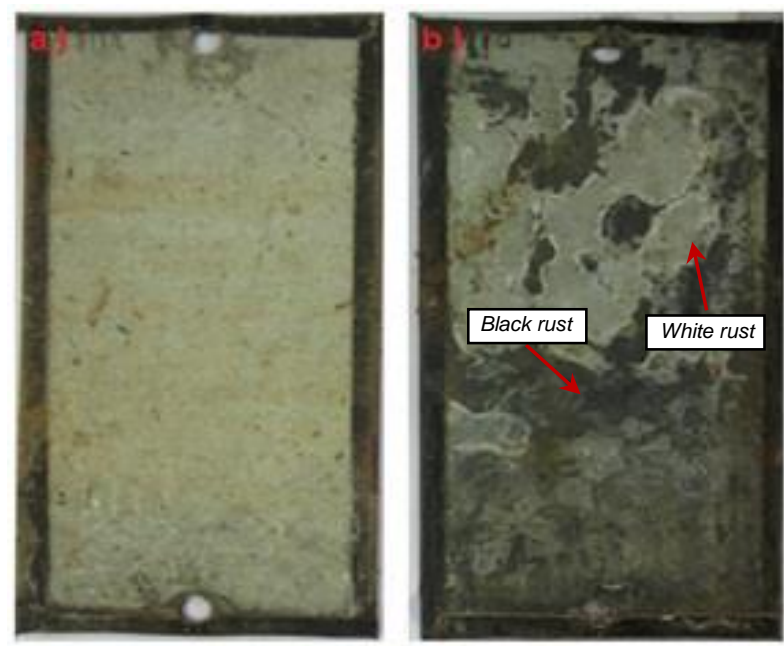

Gambar 4. Visualisasi spesimen setelah ekspos pada: a) permukaan sungai, b) kedalaman 1 meter.

Tabel 2. Hasil parameter kualitas air sungai.

\begin{tabular}{ccccccc}
\hline Waktu & Temp. & \multicolumn{3}{c}{ Salinitas Kondutivitas } & DO & TDS \\
Ekspos & $\left({ }^{\circ} \mathbf{C}\right)$ & $\mathbf{p H}$ & $(\mathbf{p p t})$ & $(\mu \mathbf{s} / \mathbf{c m})$ & $(\mathbf{m g} / \mathbf{L})$ & $(\mathbf{m g} / \mathbf{L})$ \\
\hline 0 & 27,1 & 6,92 & 0,33 & 667 & 6,23 & 332 \\
27 & 27,2 & 6,86 & 0,5 & 1018 & 4,95 & 500 \\
76 & 25,5 & 7,61 & 0,03 & 61,5 & 8,3 & 28,8 \\
\hline
\end{tabular}

\subsection{Pengaruh Parameter Air}

\subsubsection{Salinitas}

Salinitas (kadar garam) didefinisikan sebagai banyaknya kandungan garam zat-zat terlarut dalam 1000 gram air. Peningkatan ion klorida $\left(\mathrm{Cl}^{-}\right)$dan konduktivitas dalam air dapat menyebabkan logam menjadi sangat korosi. Semakin besar kadar garam (salinitas) maka semakin besar klorida dan konduktivitas yang terkandung sehingga mempercepat laju korosi. Adanya klorida akan mempercepat laju korosi, sehingga spesimen yang diekspos pada lingkungan yang memiliki kadar garam yang tinggi akan terdegradasi dan terkorosi lebih cepat (Fachrudin and Dwi 2017; Zakowski $d k k$., 2014). Berdasarkan hasil pengukuran yang sudah dilakukan didapat hasil salinitas (kadar garam) air sungai Cidaho sebesar 0,33 \%. Dari hasil pengujian selama 27 hari dan 76 hari pada air sungai, dapat di lihat bahwa faktor salinitas relatif tidak berpengaruh karena kandungan $\mathrm{Cl}$ dibawah 1000 ppm. Hasil pengukuran salinitas mengindikasikan bahwa air sungai Cidaho termasuk ke dalam kategori air segar (fresh water), karena kandungan klorinnya dibawah 1000 ppm (Roberge 2008).

\subsection{2 pH (Tingkat Keasaman)}

Berdasarkan hasil pengukuran yang dilakukan diketahui bahwa $\mathrm{pH}$ (keasaman) lingkungan air sugai Cidaho realtif sama selama waktu ekspos yakni sekitar 6,86 sampai 7,61. Hasil laju korosi baja galvanis tidak tergantung pada $\mathrm{pH}$ karena air dilingkungan sungai Cidaho memiliki nilai $\mathrm{pH}$ netral. Berbeda jika baja galvanis diekspos dilingkungan air laut, maka nilai laju korosi baja galvanis semakin besar dengan semakin asamnya air laut (Prifiharni $d k k$., 2017).

$\mathrm{pH}$ air sangat penting karena jika nilai $\mathrm{pH}$ di bawah 5,5, maka laju korosi zinc meningkat tajam kecuali ada inhibitor. Produk korosi galvanis dalam kondisi asam $(\mathrm{pH}$ $<5,5)$ seperti dalam lingkungan klorida, sulfat, dan asetat mudah larut dalam air. Dalam larutan alkali yang kuat $(\mathrm{pH}>12,5)$, akan terbentuk zincat yang larut dalam air sehingga dengan demikian serangan korosi menjadi tidak terhalang dalam lingkungan yang sangat asam atau basa. Oleh karenanya penggunaan galvanizing (zinc) sesuai pada lingkungan yang memiliki $\mathrm{pH}$ anata 5,5 samapai 12,5 (Revie and Uhlig 2008).

\subsubsection{Total Padatan Terlarut (TDS)}

Total padatan terlarut (TDS) adalah jumlah partikel yang terlarut dalam air sungai atau dikenal dengan tingkat kekeruhan air. Laju korosi lebih besar pada lingkungan air dengan nilai TDS yang tinggi karena banyak terjadi gesekan pada permukaan logam yang diekspos akibat banyak partikel dalam media air (Rose $d k k ., 2012$ ). Berdasarkan pengukuran yang telah dilakukan diperoleh nilai TDS air sungai Cidaho awalnya sebesar $332 \mathrm{mg} / \mathrm{L}$. Hasil pengukuran TDS air sungai Cidaho pada 27 hari dan 76 hari masing-masing sebesar $500 \mathrm{mg} / \mathrm{L}$ dan $28,8 \mathrm{mg} / \mathrm{L}$. Dari hasil pengujian dapat di lihat bahwa nilai laju korosi menjadi besar pada air yang mempunyai TDS tinggi.

\subsubsection{Oksigen Terlarut (DO)}

Distribusi oksigen yang seragam di dalam air berpengaruh signifikan terhadap laju korosi (Ismail and Adan 2014). Besarnya oksigen terlarut (DO) dari hasil 


\section{TEKNIK, 41 (1), 2020, 24}

pengukuran sebelum diekspos lebih tinggi daripada pengukuran ke 27 hari dan meningkat pada ke 76 hari. Hasil pengukuran DO untuk 27 hari dan 76 hari masingmasing sebesar 4,95 dan $8,3 \mathrm{mg} / \mathrm{L}$ seperti disajikan dalam Tabel 2. Pada 27 hari ekspos, DO dari air sungai menurun dengan terjadinya proses korosi, karena pengurangan katodik oksigen terlarut terjadi dalam kondisi larutan netral dalam reaksi seperti terlihat pada Persamaan 7.

$$
\mathrm{O}_{2}+2 \mathrm{H}_{2} \mathrm{O}+4^{\mathrm{e}-} \rightarrow 4 \mathrm{OH}
$$

Setelah 76 hari ekspos, proses korosi baja galvanis terus berlangsung dengan kandungan DO meningkat karena terhalang oleh endapan.

Endapan padat atau homogenitas lainnya pada permukaan galvanis dapat menginduksi pembentukan sel aerasi diferensial dengan zinc yang diserang. Sel aerasi diferensial terbukti dalam beberapa aspek korosi galvanis, terutama dalam pembentukan noda dalam lingkungan yang mengandung air (Roberge 2008).

\subsubsection{Suhu}

Setiap reaksi kimia dipercepat oleh kenaikan suhu. Secara umum, kecepatan reaksi meningkat signifikan dengan setiap kenaikan suhu $10{ }^{\circ} \mathrm{C}$ (Asadi $d k k$., 2015). Fenomena ini juga berlaku pada korosi galvanis di lingkungan air, tetapi ada faktor lain yang memperlambat korosi, seperti pengendapan karbonat atau pengurangan udara atau oksigen terlarut.

Pada suhu rendah, endapan padat dapat terbentuk sedangkan pada suhu lebih tinggi akan meningkatkan porositas dan mengurangi perlindungan korosi. Data hasil pengukuran suhu air sungai pada Tabel 2 terlihat bahwa suhu air sungai relatif sama yaitu berkisar antara $25,5{ }^{\circ} \mathrm{C}$ sampai $27,2{ }^{\circ} \mathrm{C}$. Dari hasil pengukuran suhu yang relatif sama dapat dikatakan bahwa pengaruh suhu pada laju korosi baja galvanis relatif kecil.

\subsection{Produk Korosi}

Gambar SEM dari spesimen baja galvanis ditunjukkan pada Gambar 5. Spesimen diekspos selama 76 hari di lingkungan air sungai Cidaho-Sukabumi. Perbedaan ketinggian permukaan terlihat pada kedua spesimen yang diekspos pada permukaan air dengan spesimen yang diekspos di kedalaman 1 meter. Pada spesimen di permukaan air menunjukkan permukaan yang hampir seragam (Gambar 5-a). Terlihat sisa lapisan galvanis pada spesimen yang diekspos di kedalaman 1 meter lebih tipis dibandingkan pada spesimen di atas permukaan air sungai. Hasil ini mengkonfirmasi bahwa kerusakan permukaan baja galvanis pada kedalaman 1 meter lebih besar dibandingkan dengan kerusakan permukaan baja galvanis pada permukaan air. Hasil foto morfologi ini konsisten dengan hasil metode pengurangan berat.

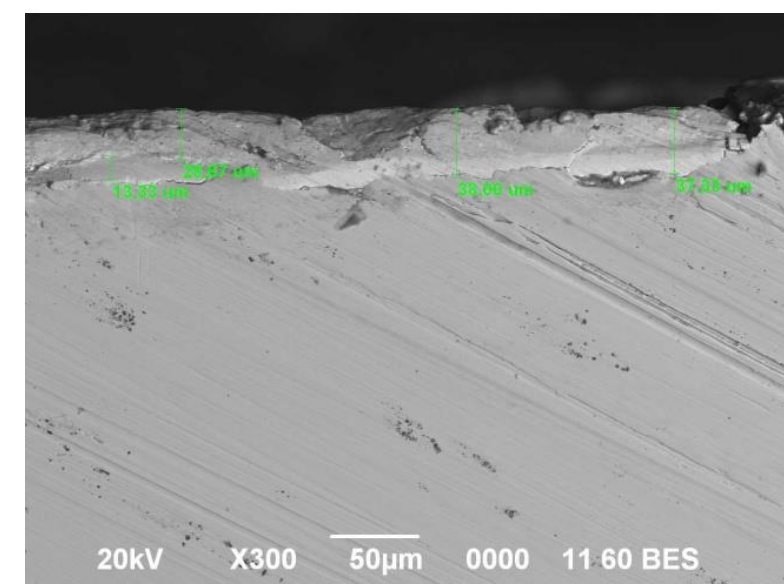

a). Permukaan air ( 0 meter ).

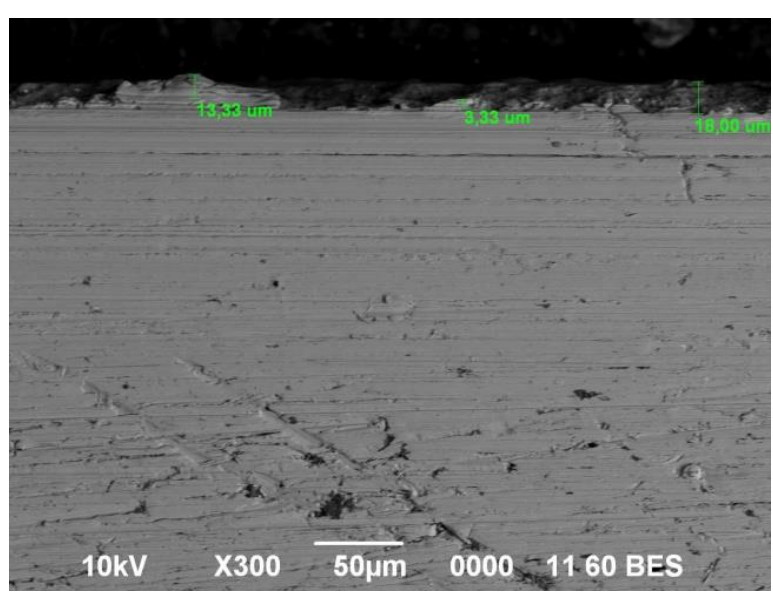

b). Kedalaman 1 meter dari permukaan air.

Gambar 5. Hasil foto SEM baja galvanis setelah ekspos.

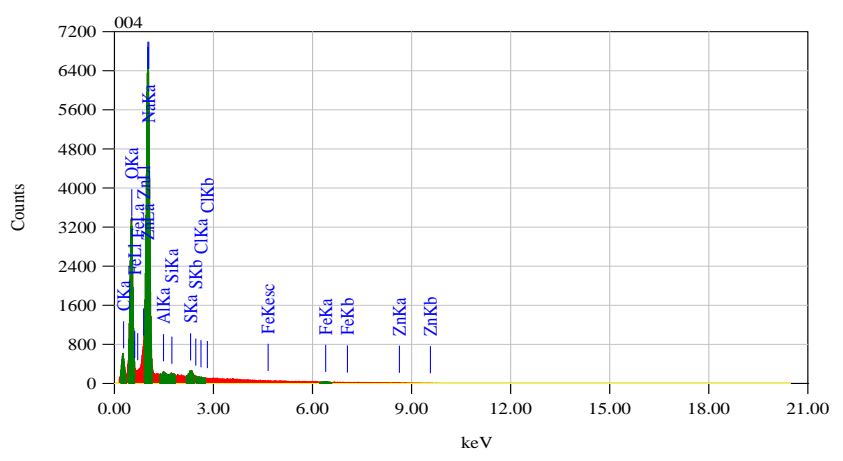

Gambar 6. Hasil EDS produk korosi.

Hasill analisis EDS permukaan spesimen baja galvanis setelah diekspos selama 76 hari pada Gambar 6. Produk korosi mengandung unsur zinc, besi, oksigen, karbon dan natrium. Hasil ini memperkuat bahwa senyawa yang terbentuk pada produk korosi didominasi oleh senyawa Zincite $(\mathrm{ZnO})$ sebagaimana hasil analisis pada X-Ray Diffraction (XRD) dalam Gambar 7. 


\section{TEKNIK, 41 (1), 2020, 25}

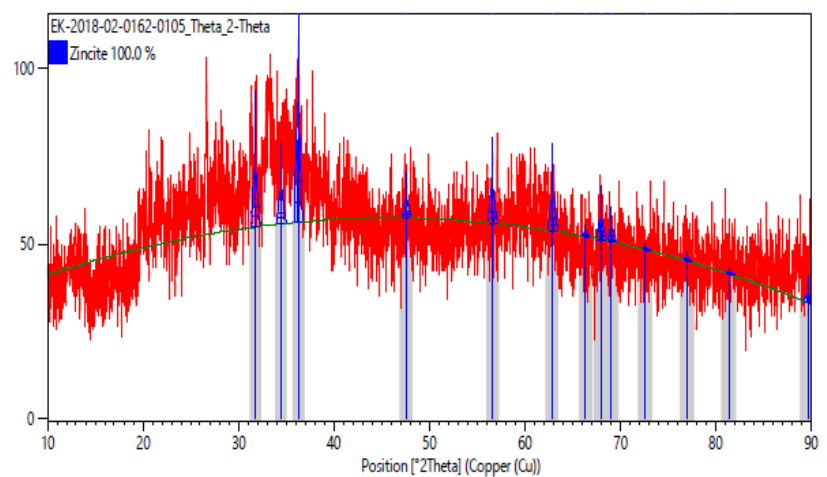

Gambar 7. Pola X-Ray Diiffraction (XRD) dari produk korosi.

\section{Kesimpulan}

Kerusakan baja galvanis pada daerah lingkungan air sungai dipengaruh oleh waktu dan kedalaman ekspos. Kerusakan baja galvanis di kedalaman 1 meter lebih besar daripada di permukaan air sungai. Hasil kehilangan berat baja galvanis setelah diekspos 76 hari adalah $1,37 \mathrm{mg} / \mathrm{cm}^{2}$ di permukaan air sungai dan 7,83 $\mathrm{mg} / \mathrm{cm}^{2}$ pada kedalaman 1 meter. Peningkatan kerusakan baja galvanis di kedalaman air terjadi karena tidak terbentuk lapisan protektif akibat tergerus arus sungai. Produk korosi yang dominan pada baja galvanis yang diekspos pada kedalaman 1 meter adalah senyawa Zincite $(\mathrm{ZnO})$. Hasil ini mengindikasikan bahwa penggunaan baja galvanis tidak cocok untuk lingkungan di kedalaman air.

\section{Ucapan Terima Kasih}

Ucapan terima kasih penulis sampaikan kepada Pusat Penelitian Metalurgi dan Material - LIPI dan Pusjatan - Kementerian PUPR atas dukungan fasilitas dan sarana dalam kegiatan penelitian ini.

\section{Daftar Pustaka}

Asadi, V., Danaee, I., Eskandari. (2015). The Effect of Immersion Time and Immersion Temperature on the Corrosion Behavior of Zinc Phosphate Conversion Coatings on Carbon Steel. Materials Research 18 (4), 706-713.

ASTM Committee G1. (1999) Standard Practice for Preparing, Cleaning, and Evaluating Corrosion Test Specimens. Book of ASTM Standards. G01$05,15-21$.

Bednar, L. (2015). Plain Galvanized Steel Drainage Pipe Durability Estimation with a Modified California Chart. Transportation Research Record, 1231, 7079.

Bhaskaran, R.N., Palaniswamy, N.S., Rengaswamy, Jayachandran, M. (2005). A review of differing approaches used to estimate the cost of corrosion (and their relevance in the development of modern corrosion prevention andp control strategies). AntiCorrosion Methods and Materials, 52(1), 29-41.

Fachrudin, T. D., Dwi, H. S. (2017). Laju Korosi Pipa Galvanis (Inlet Desalinasi) Pada Sea Chest Kapal Terhadap Waktu dan Salinitas Air Laut. JTM 5(3), 87-94.

Huyuan, S., Shuan, L., Lijuan, S. (2013). A Comparative Study on the Corrosion of Galvanized Steel under Simulated Rust Layer Solution with and without $3.5 \mathrm{wt} \% \mathrm{NaCl}$. Int. J. Electrochem. Sci., 8, 34943509.

Irving, A., Denison, Melvin, R. (1952). Corrosion of Galvanized Steel in Soils. Journal of Research of the National Bureau of Standards. 49(5), 299-314.

Ismail, A., Adan, N. H. (2014). Effect of Oxygen Concentration on Corrosion Rate of Carbon Steel in Seawater. American J. of Eng. Research), 3(1), 64-67.

Merajul, H., S. Alam, L., Moniruzzaman, Mohar, A. B. (2014). Corrosion Comparison of Galvanized Steel and Aluminum in Aqueous Environments. International Journal of Automotive and Mechanical Engineering, 9, 1758-1767.

Moniruzzaman, M., Mohar, A. B., Merajul, H. M., Limon, S. A. (2013). Corrosion of Galvanized Steel and Copper in Aqueous Environments. Journal of Mechanical Engineering, 43(2), 61-67.

Prifiharni, S., Nuraini, L., Priyotomo, G., Sundjono, Gunawan, H., Ibrahim, P. (2017). Corrosion Performance of Steel and Galvanized Steel in Karangsong and Limbangan Sea Water Environment. Proc. of the Int. Seminar on Metallurgy \& Materials (ISMM2017) AIP Conf. Proc, 1964, 020038-1 - 020038-6.

Revie, R.W., Uhlig, H.H. (2008). Corrosion and Corrosion Control: An Introduction to Corrosion Science and Engineering. Fourth Edition. Canada: John Wiley \& Sons.

Rita, M., Figueira, Elsa, V. P., Carlos J.R. Silva., Maria, M. S. (2013). Corrosion Protection of Hot Dip Galvanized Steel in Mortar. Portugaliae Electrochimica Acta, 31(5), 277-287.

Roberge, P.R. (2008). Corrosion Engineering: Principles and Practice. New York: McGraw-Hill.

Rose, A.L., Rani, F.R.S., Regis, A.P.P., Rose, C.M. (2012). Corrosion behaviour of carbon steel in river water in the presence of Lactic acid-Zn2+ system. Int.J. ChemTech Research, 4(1), 157-164.

Roseana, F. C. P., Edkarlla, S. D. O., Maria, A. G. A. L., Simone, L. D. C. B. (2015). Corrosion of Galvanized Steel Under Different Soil Moisture Contents. Materials Research, 18(3), 563-568. 


\section{TEKNIK, 41 (1), 2020, 26}

Royani A, Prifiharni S, Priyotomo G, Triwardono J, Sundjono. (2019). Performa Korosi Baja Karbon Pada Uji Simulasi Pipa Untuk Sistem Saluran Air Pendingin. Metalurgi, 34(2), 49-60.

Royani, A., Nuraini, L., Prifiharni, S., Priyotomo, G., Sundjono. (2018). Corrosion Rate of Various Carbon Steels in Raw Water for Water Cooling System at Ammonia Plant. Int. J. of Eng. Trends \& Tech, 59(1), 51-58.

Shuan, L., Huyuan, S., Zhang, N., Lijuan, S. (2013). The Corrosion Performance of Galvanized Steel in Closed Rusty Seawater. International Journal of Corrosion, 1-9
Sundjono, Priyotomo, G., Nuraini, L., Prifiharni, S. (2017). Corrosion Behavior of Mild Steel in Seawater from Northern Coast of Java and Southern Coast of Bali, Indonesia. J. Eng. Technol. Sci, 9(6), 770-784.

Zakowski, K., Narozny, M., Szocinski, M., Darowicki, K.. (2014). Influence of Water Salinity on Corrosion Risk - The Case of the Southern Baltic Sea Coast. Environ Monit Assess, 186. 